\title{
Community supported agriculture in the city: The case of Toronto
}

\author{
Sima Patel ${ }^{\mathrm{a}}$, York University \\ Rod MacRae ${ }^{\mathrm{b}, *}$, York University
}

Submitted 24 November 2011 / Revised 25 January 2012, 10 February 2012 / Accepted 28 June 2012 /

Published online 10 August 2012

Citation: Patel, S., \& MacRae, R. (2012). Community supported agriculture in the city: The case of Toronto. Journal of Agriculture, Food Systems, and Community Development, 2(4), 85-100. http://dx.doi.org/10.5304/jafscd.2012.024.003

Copyright (C) 2012 by New Leaf Associates, Inc.

\begin{abstract}
Farming in cities is gaining momentum within North American urban centers. Community supported agriculture (CSA) projects, previously viewed primarily as rural enterprises, are now starting to appear in cities, including Toronto. Urban CSAs address the new food movement's objectives as they can provide good food that is accessible, an income to those growing the food, education on how food is grown, and show the importance of environmental stewardship and the recycling of resources. We used land parcel analysis to examine the potential for vegetable CSAs in Toronto, identifying 77 parcels with a total of 1270 acres (514 hectares) of potential land for CSA
\end{abstract}

${ }^{a}$ MES graduate, Faculty of Environmental Studies, York University; essvpatel@gmail.com

b, * Corresponding author: Rod MacRae, Associate Professor, Faculty of Environmental Studies; York University; 4700 Keele Street; Toronto, Ontario M3J 1P3 Canada; +1-416-7362100 x22116; rmacrae@yorku.ca farming, a large portion of which are located in the northeast part of Toronto. This represents about 1 percent of the city's surface area. From this analysis, five scenario types were constructed that could be commercially viable, and having a range of land use, zoning, institutional, and residential characteristics. There are considerable challenges, however, in their widespread implementation. Consequently, in this paper we make policy and program recommendations on how urban CSAs in Toronto might be advanced, including pilot projects, institutional linkages, program supports, training, and extension.

\section{Keywords}

community supported agriculture, land inventory analysis, policy change, urban farming, urban land use

\section{Introduction}

Farming in cities is gaining momentum within North American urban centers, including Toronto. 
While not a new phenomenon - urban agriculture was commonplace in cities, especially through World World II and as late as the 1950s — city farming has been making a slow, steady comeback for the past decade (Smit, Ratta \& Nasr, 1996). This growing interest in urban agriculture is evinced by the many ventures springing up in residents' yards, school grounds, abandoned lots, and institutional settings.

Currently in North America, urban agriculture initiatives come in many shapes and sizes, from small balcony tomato plants grown for pleasure to larger-scale market gardens with food security and educational goals. Urban agriculture also varies in terms of its objectives (health, aesthetics, employment, modeling different agricultural techniques, environmental awareness), management (individuals, private companies, nonprofit organizations), and products (vegetable cultivation, fruit tree harvesting, aquaculture projects, composting ventures, small livestock and poultry). It differs from rural agriculture in terms of location, scale, markets, intensity of use, social context, crop diversity, techniques, farmer organization, land ownership, and associated activities (De Zeeuw, 2004; Portland State University, 2005). Much of this burgeoning interest is related to the public recognition of environmental, social, and health challenges within the current industrial food system. These include significant greenhouse gas emissions from massive food distribution networks; considerable loss of wildlife and ecosystem biodiversity; and the impact of pesticide and antibiotic use on human health (Norberg-Hodge, Merrifield, \& Gorelick, 2002; Pretty et al., 2000; Tegtmeier \& Duffy, 2004).

One innovative response to these pressing food system problems is community supported agriculture (CSA), which emerged more than 20 years ago in North America. In its basic form, this alternative marketing method creates a closer connection between farmer and consumer, with members buying shares at the beginning of a growing season in exchange for the farm's bounty during these months. While members typically pick up produce on a weekly basis at a centralized location, they are often encouraged to visit the farm as well, in order to pick up orders, participate in farming activities, or simply observe the farm they are supporting. From its inception, CSAs sought to address a number of problems within the modern industrial food system by reconnecting farmers to consumers, supporting small farms by providing advance financing and spreading financial risk, and providing healthy food using primarily organic methods of production. In addition to the member benefits associated with receiving fresh, healthy produce at affordable prices, as well as farmers earning a decent living, other advantages exist to this type of arrangement. The ecological benefits extend beyond the use of organic growing practices, since many farmers practice conservation farming and grow a range of crops that encourages biological diversity (Willick, 2008). Many CSAs have incorporated social justice and community development in their operations by offering shares to low-income people, partnering with food banks, and running education programs (Miles \& Brown, 2005).

As the CSA concept has taken hold throughout North America, clusters have appeared in certain parts of the United States, most commonly in the Northeast and Midwest. Beginning with a couple of farms in New Hampshire and Massachusetts in the mid-1980s, the total number of CSAs has grown to over 6,000 in the United States (McFadden, 2012). There are no official Canadian statistics on CSA farms; the Ontario CSA Directory lists 200 farms on its website, while Équiterre in Quebec (an organization that boasts the largest CSA network in the world) states it has about 100 farms serving Quebec residents (Équiterre, 2011; Ontario CSA Directory, 2012). CSA farms in the U.S. and Canada tend to be small (averaging fewer than 10 acres (4 hectares) in crop production) and most are using organic or biodynamic farming methods (Équiterre, 2002; Henderson \& Van En, 2007; Organic Council of Ontario [OCO], 2009). Current statistics are also limited on the number of people belonging to CSAs, especially in Canada. In Quebec, Équiterre claims that the farms in its network offer products through the CSA model to more than 30,000 members (Équiterre, 2011). While formal statistics on CSA membership within the city of Toronto are not readily available, it was estimated that there are approximately 14 rural 
CSAs serving the Toronto area, providing about 1,200 shares. This number does not include organic produce home delivery services, of which there are a number in the city. This statistic also does not include the more than 4,000 Good Food Boxes (GFB) distributed monthly in Toronto, a weekly fruit and vegetable box program subsidized by the nonprofit organization FoodShare in an effort to get more affordable, healthy food into Toronto households (Biberstein \& Daalderop, 2008).

While CSAs endeavor to connect members to the farm, the reality is that most CSA farms are located at quite a distance from any large city, Toronto included. Most members only rarely have the opportunity to visit the farms to which they belong and actually connect to the source of their food. It is for this reason that the potential for CSAs within the city of Toronto was explored. Urban CSAs may be a way to address objectives of the new food movement. They can provide good food that is accessible to many people; provide an income to those growing the food (especially when the right supports are in place); educate people on how food is grown; and show the importance of environmental stewardship and the recycling of resources. As evidence of this potential, recently at least three farming operations in Toronto led by young farm entrepreneurs have started CSAs using backyard production. Two research papers were recently published in the Journal of Agriculture, Food Systems, and Community Development on scaling up urban agriculture in Toronto (MacRae, Gallant, Patel, Michalak, Bunch, \& Schaffner, 2010; MacRae et al., 2012). The MacRae et al. (2010) study examined the potential for vegetable production on land located within the city of Toronto. This study brings together the two arenas of urban agriculture and community supported agriculture, examining urban CSA possibilities in Toronto through more in-depth analysis of the land parcels identified in the MacRae et al. (2010) paper. Thus, we use relatively current spatial data to construct a vision of possibilities. Many of these ideas are taken from innovative CSA and urban agriculture initiatives in Toronto and other cities. We also present potential opportunities and challenges associated with establishing CSA farms within the city of Toronto.
Municipalities such as Vancouver, Portland, Seattle, and Oakland have undertaken land inventory projects to examine how much land is actually available for farming within their cities (Horst, 2008; Kaethler, 2006; McClintock \& Cooper, 2009; Portland State University, 2005). While this is an important first step in supporting urban agriculture, programming activities (i.e., how the land could or should be used and the transition process supported) have received far less attention. While the focus of this paper is on Toronto, many of the lessons learned could be applied to other municipalities.

\section{Literature Review}

An important first step in determining the feasibility of CSAs on city land is to examine and formulate criteria for establishing a successful CSA operation in the city. This means considering conditions both similar to rural areas and unique to the urban setting.

Both rural and urban farmers, in looking at the physical characteristics of the land, consider soil type, depth, $\mathrm{pH}$, organic content, nutrients, aspect, slope, air drainage, wind protection, and amount of sunshine (Coleman, 1995). However, urban farmers more frequently must also investigate contamination from heavy metals and persistent chemicals (FoodShare, 2008).

Access to water, roads, and other infrastructural components such as fencing and electricity are important for the successful operation of an urban farm (FoodShare, 2008). It is critical, especially in an urban setting, to take note of structures on the property as well as buildings in close proximity to the parcel (FoodShare, 2008).

From an administrative perspective, information on ownership, zoning, site history, and future plans provide an indication of whether there will be political challenges to establishing an urban farm. In an urban setting, where neighborhoods are stitched closely together, it is important to consider how the local community will receive the venture. This involves looking not only at what services are available, but also at potential partners to collaborate on operating the farm. Most importantly, the costs of renting or owning urban land for farming contrast greatly with rural settings. 
Operating CSAs in cities may require the engagement of a wider array of actors and support from municipal governments to make the ventures viable.

\section{Elements of a Successful CSA}

Success for a CSA is defined as financial solvency for the farmer, affordability for the average consumer, provision of healthful food, care of the land, and personal connection to the farm on the part of the members. In addition to the physical characteristics of the land and setting, many other factors play into the success of a CSA farm. Farmers face numerous challenges, including high member turnover rates; members may leave due to lack of choice if weekly baskets do not match their eating patterns or require too much planning. They also may leave if picking up on a specific day and time each week proves to be inconvenient. Other challenges are high land values, membership administration and communication, and the demands of producing consistent amounts of produce week after week (Henderson \& Van En, 2007; OCO, 2009). Based on the literature (Coleman, 1995; Équiterre, 2002; Goland, 2002; Henderson \& Van En, 2007; Lang, 2005; Lass, Stevenson, Hendrickson, \& Ruhf, 2003; OCO, 2009; Russell \& Zepeda, 2008; Tegtmeier \& Duffy, 2005; Willick, 2008; Worden, 2004), many criteria determining the success of a CSA farm in rural and suburban settings appear also to be applicable to urban settings. These criteria are summarized below.

\section{Site and Crop Production}

- The CSA provides a wide variety of vegetables (at least 30), plus fruit if possible, over a normal growing season (at least 18 weeks).

- $\quad$ The CSA is able to sell between 100 and 200 shares, which would require a minimum of 5 acres ( 2 hectares) for crop production.

- There are structures such as greenhouses, storage space, and a workstation on-site or in the vicinity.

- The farmer is able to create soil fertility on-site or access appropriate soil amendments at affordable prices.
- The farm is located as close as possible to members so that distribution is simple, inexpensive, and contributes to members being more attached to the farm.

\section{Organizational Structure}

- The farmer is experienced with organic methods of growing, as well as with the CSA model. (While CSA farms do not have to be organic, most are, and research indicates that members are often attracted to the model and remain members - for environmental reasons (Goland, 2002)).

- The farmer or a staff member is willing to interact with people on a regular basis.

- A core group of members are willing to take on administrative tasks to keep the CSA running smoothly (e.g., arranging deliveries, emailing members, and gathering and distributing recipes).

- There is access to good, affordable labor, and the farm provides fair working conditions.

- The farmer or another staff member is able to connect with food organizations and other community agencies.

\section{Economics and Legalities}

- The farmer is able to sell shares at a fair price.

- The farmer is able to supplement the CSA income with other income or savings for the first few years.

- The farmer is able to be flexible in terms of payment (without compromising his or her own finances), such as accepting two or three payments throughout the season.

- Ownership of the land is the ideal situation; if ownership not possible, the next best option is renting land from an organization that is socially and/or environmentally conscious and willing to lease on a long-term basis at below market rent. A minimum five year rolling lease is ideal.

\section{Member Relations}

- The farmer is able to explain to members from the outset what being a part of the CSA entails. 
- The members (or one member of the household) are strongly encouraged or required to work on the farm.

- The farmer is able to provide as much choice as possible in terms of produce for the basket; providing recipes and suggestions with each basket is helpful.

- The farmer is able to modify crop planning to create shares that cater to a specific ethnic community.

- Broad concepts of sustainability are in place for other aspects of the operation (e.g., how produce is packaged, alternative transport).

While most farmers do not meet all of the criteria, the elements described provide a picture of factors that play into the success of a CSA farm.

\section{Methods}

This paper is focused on commercial vegetable production CSAs, even though there are many other activities (animal husbandry, agroforestry, processing) that can fall under the umbrella of urban agriculture. One of the reasons for this is that most existing CSAs provide vegetables and fruit, and available research focuses on these types of CSAs. In addition, vegetable production allows a broader forum to discuss healthy eating and organic agriculture. Finally, with legalities prohibiting other types of urban agriculture, such as raising animals within cities, utilizing offproperty waste for compost, and planting fruit trees in public spaces, it is difficult to find examples and research on these activities.

\section{Land Parcel Analysis}

This section provides a brief overview of the parcel analysis completed by MacRae et al. (2010), followed by a description of the methods used to perform this follow-up study. It is important to note that only land-based parcels were assessed in the original study; while there is tremendous opportunity for existing rooftop space to be used for growing food, it is not addressed in this paper. Using 2005 data and geographical information systems (GIS), MacRae et al. (2010) performed a parcel analysis to identify potential land for agricultural use within the city of Toronto. The main screening criteria were based on size, shape, site coverage, accessibility, proximity to watercourses, and proximity to roads. The city regions of Scarborough and Etobicoke were the focus of the land inventory analysis due to the continued existence of agricultural land in certain areas and large amounts of potential agricultural land as well (MacRae et al., 2010).

The minimum size considered was one acre (0.4 hectare), with an exception for parcels smaller than that size in cases where there were two small parcels in close proximity. In terms of shape, the ability of a small tractor to efficiently work the land was considered in the exclusion of most curvilinear-shaped parcels. Parcels where the land was covered in constructed material (e.g., buildings, pavement), transportation routes (e.g., roads, trails, paths), active recreation space (e.g., soccer pitches), active utility corridors, forests, and water were excluded from consideration. Land was also excluded if it contained no visible access point or access was impeded by things such as recreation space or extensive manicured lawns. To minimize contaminants in waterways and from traffic on roads, a 16 foot (five meter) buffer was used from all streams and rivers, as well as a 33 foot (10 meter) buffer from roads. Use of park space was limited to those areas of parks where there may be underutilization; parcels were not considered if they were the central point of the park or if they constituted more than one third of the total area of the park (MacRae et al., 2010).

Due to lack of readily available data, MacRae et al. (2010) were unable to factor in access to water, contamination issues, development pressures, and ownership. See figures 1 and 2 for maps of parcels in the initial study, located in the Etobicoke and Scarborough regions of Toronto.

\section{Examination of Parcels}

To gain an understanding of CSA possibilities, a select number of parcels identified in the MacRae et al. (2010) analysis were chosen for site visits and more in-depth analysis. The selection of sites to visit was not altogether random: one of the goals was to look at larger parcels, as they would offer the most potential for the establishment of a CSA farm. The northeast part of Scarborough contained 
the majority of these larger parcels, and thus these were included in the site visits. It also made sense to visit parcels that were in close proximity to each other; therefore, parts of the city where there were small, disparate parcels were less likely to be included in the site visits.

The process of gathering the information on these parcels is summarized below.

1. Maps were obtained from MacRae et al. (2010).

2. Over the course of 3 months, we completed site visits on 150 parcels, selected as described above. The number of parcels chosen was determined by those that appeared to lend themselves best to urban farming possibilities and how many could be visited in the time available.

3. We also examined the sites using aerial maps on a website providing current aerial data (http://www.maps.live.com). This allowed a
Figure 1. Post-Ground Truthing Agricultural Parcels in Etobicoke

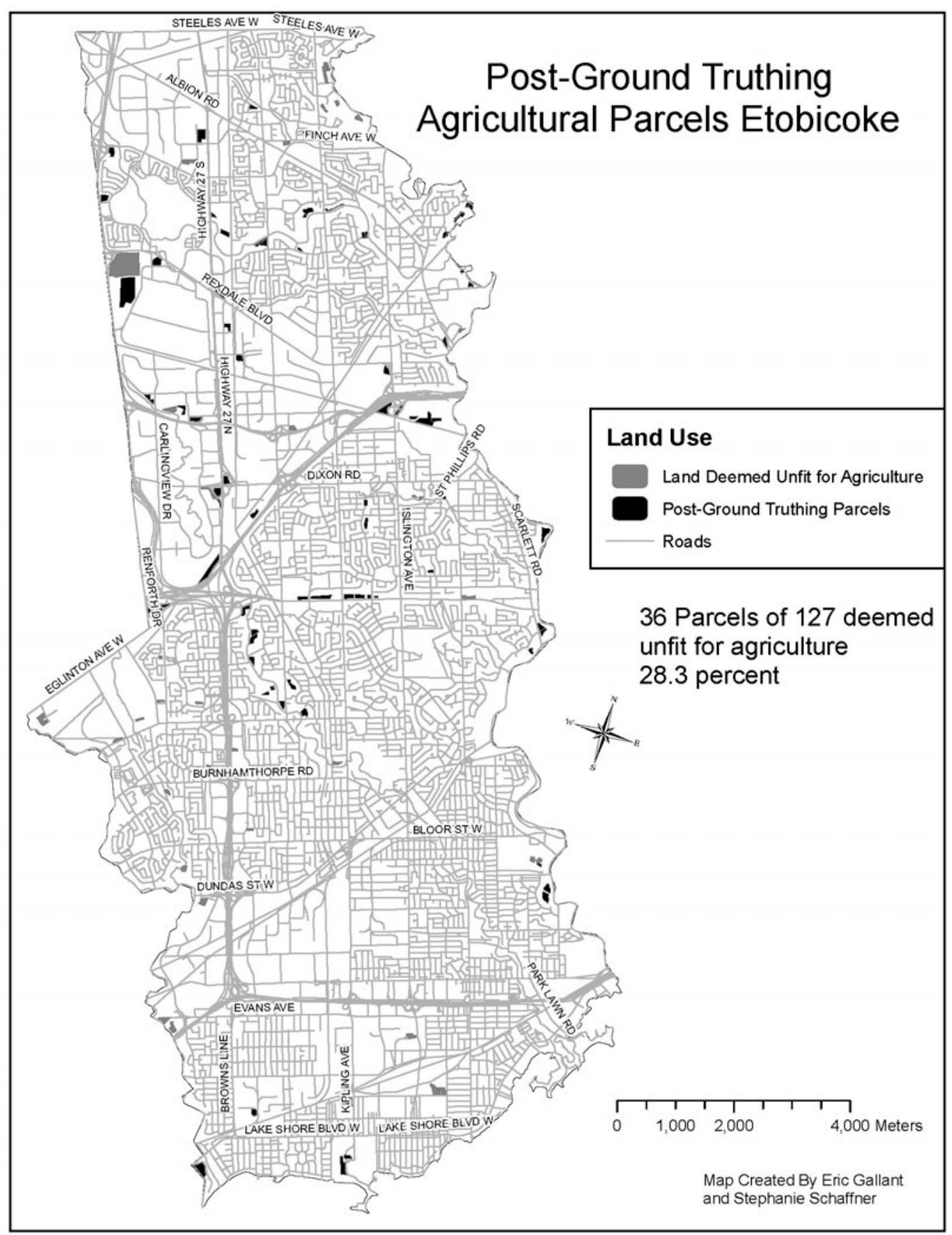

more detailed look at certain parcels that may not have been easy to look at from the ground, due to borders of trees, for example.

4. To gain ownership and development plan information, the City Planning Department, along with the Facilities and Real Estate Department, were able to provide general 
Figure 2. Post-Ground Truthing Agricultural Parcels in Scarborough

\section{Post-Ground Truthing Agricultural Parcels Scarborough}

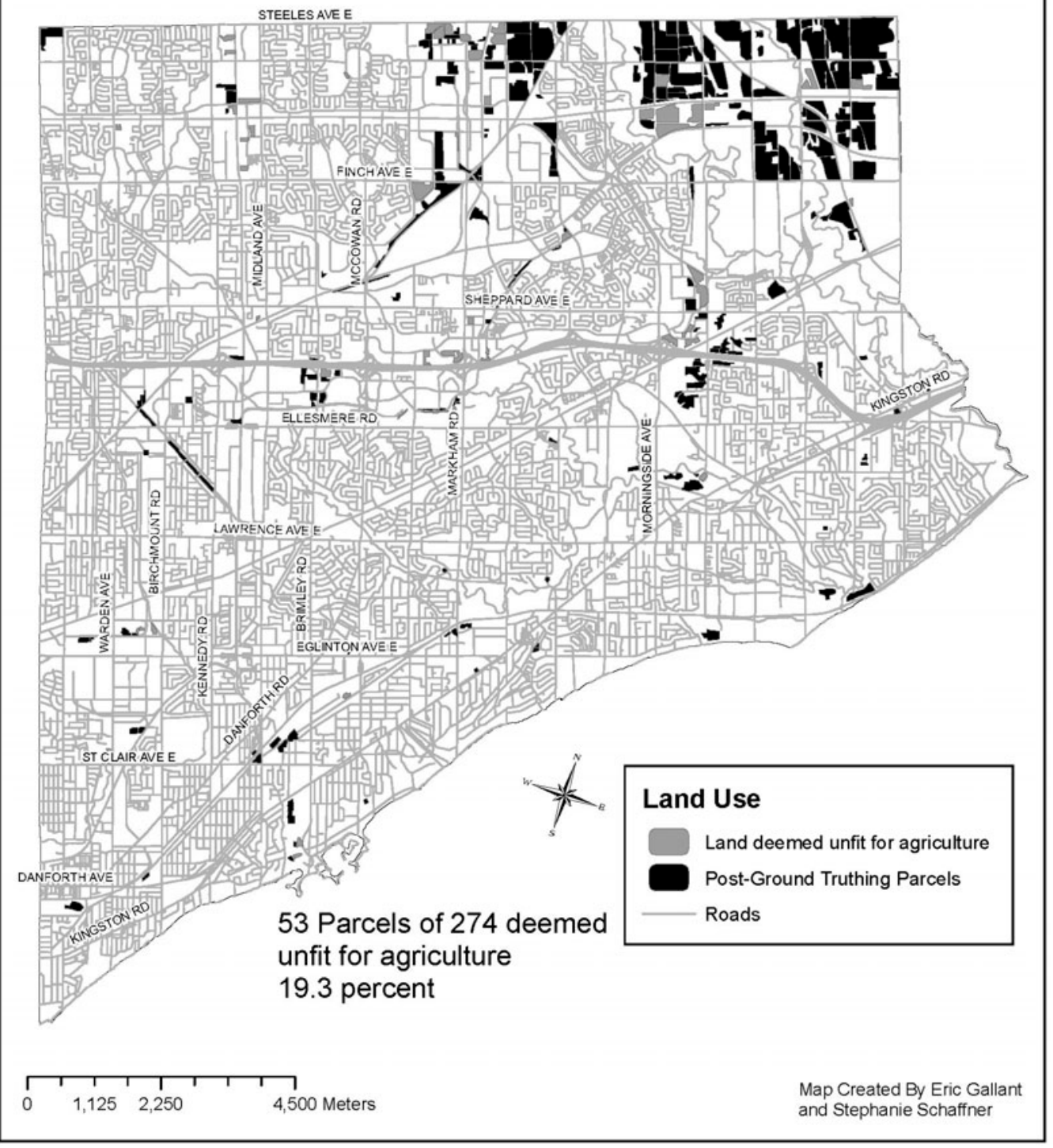

Rouge Park of

North East

Scarborough, which are managed by the Toronto and Region Conservation Authority (TRCA). ${ }^{1}$

5. To find out specific

ownership information, we utilized the Ontario Land Registry, which maintains electronic records on ownership information and history (obtainable for a fee).

6. To obtain zoning and land use designation, we consulted city of Toronto websites (http://www.tor onto.ca/plannin $\mathrm{g} /$ official_plan/i ntroduction.htm and

http://www.tor onto.ca/zoning). 7. Utilizing city of Toronto Social

information on whether there were development plans pending for any particular parcel. While they were not able to disclose specific ownership information, they were able to say whether any given parcel was owned by the city. Some ownership information was already known, such as parcels within the
Development Department Statistics, we obtained information on population, ethnicity, language, income, and other demographic data.

\footnotetext{
${ }^{1}$ As this paper goes to press, the Rouge Park is being transferred from the TRCA to Canada's national park system. It is not clear yet what this means for agriculture in the park.
} 
8. Using the Internet as well as contacting key people at various organizations, we obtained information on schools, food organizations, and relevant social services.

\section{Limitations}

There are many limitations to the data collection and findings that bear mentioning. It was not possible to obtain complete and relevant information on all parcels due to time, budget, and legal constraints. For example, finding out specific ownership information from the Ontario Land Registry can become an expensive process, as information on each parcel of land incurs a separate fee. In addition, certain information is only available through city departments, which are not always able to share data due to privacy legislation. Overall, 30 percent of the total parcels received site visits. Because they were not completely randomly chosen, it is difficult to extrapolate the findings to the sites not visited.

In order to properly assess the agricultural potential of a piece of land, it is important to have a multidisciplinary approach that involves people with backgrounds in planning, food production, construction, and architecture (Mougeot, 2006). It was not possible in this research process to draw on all this expertise.

\section{Results}

Of the parcels mapped out in the initial GIS data (see figures 1 and 2), 150 parcels received a site visit. Based on criteria laid out in the previous section, 73 of these parcels were excluded, leaving 77 for further study. These 77 parcels translate into a total of 1,270 acres, or 514 hectares (about one percent of the city's surface area), of potential land for CSA farming, a large portion of which are located in the northeast part of Scarborough.

\section{Scenarios}

Singling out select parcels for more detailed study is a useful way to study the challenges and opportunities facing CSA farms in the city. For the scenarios in this section, we chose parcels that highlighted characteristic opportunities and challenges to their implementation as CSA farms, with the hope that a wide cross-section of possibilities could be examined. From the broad spectrum of parcels that were examined and determined suitable for agricultural activities, five different types of parcels of land are presented.

It is important to note that the following scenarios presuppose municipal interventions to address policy and regulatory barriers, funding, and administrative support. MacRae et al. (2012) provide details on applicable program supports that could help with scaling up urban agriculture within the city of Toronto. Their proposals include the creation of a governing body performing a full land inventory analysis; a system for matching land with farmers; lease arrangements; support for infrastructure establishment (water, compost, etc.); zoning; and assistance with community consultation.

\section{(a) Institutional land scenario}

Several parcels of land identified as suitable for CSA farms are located on or adjacent to institutions such as public schools, universities and colleges, places of worship, and religious education centers. An increasing number of institutions are incorporating food production into school curriculum, university research, and ecumenical services. Some recent examples just outside the official Toronto border include the partnership between the University of Toronto Mississauga (UTM) and the Mississauga Sustainable Urban Agriculture Project (MSURA), an initiative of EcoSource, which is an environmental nonprofit organization based in Peel Region just west of Toronto. UTM students work with EcoSource to complete internships using the MSURA urban farm demonstration site as a focus for broadening understanding in areas such as science education, food security, and environmental sustainability. Another example is the Kavanah Garden, an organic educational garden offered through the Shoresh Jewish Environmental Programs in Vaughan, Ontario. The garden is also involved with the Cutting Veg, a CSA farm located in Sutton, Ontario; much of the food grown in the garden is donated to community members in need. As these and many other projects demonstrate, a wide range of opportunities exist in addition to the act of growing food when food production occurs at institutional sites. These sites offer many advantages, including 
uncontaminated land, infrastructural components, and a large pool of potential labor and members.

This scenario is based on a 9.5 acre $(3.8$ hectare) parcel of land adjacent to a religious institution in southeast Scarborough. The land is in mowed grass, contains a water hydrant, has no structures on it, and has not had any development since being in agriculture in the 1960s. One side of the parcel is abutted by residential backyards. The parcel is zoned as "Institutional" and is owned by a religious organization.

One challenge with this type of parcel is zoning. Many institutional parcels do not allow farming activities, and therefore zoning would need to be amended or temporary use permits enacted in order for agriculture to occur and its products marketed. Due to proximity to neighbors, another challenge could be the possibility of opposition to this kind of venture due to concern around noise, increased traffic, and potential vandalism. Also, during the summer months when the majority of crop production occurs, many students may not be available to participate in farming activities in school or university settings.

\section{(b) Agricultural land scenario}

The largest number of parcels identified as potential CSA farm sites in the original study were located in Rouge Park, in the northeast part of Scarborough.

This scenario is based on one of the larger parcels identified, measuring approximately 110 acres (44.5 hectares), and currently set in active farmland. There are several structures on-site, including a residence, barn, and silos. It sits on the border between Scarborough, Markham, and Pickering, and is surrounded by other farmed and fallow land. It is zoned for agriculture and is owned by the Toronto and Region Conservation Authority (TRCA).

There are several opportunities associated with establishing CSA farms on these parcels. With the land already zoned for agriculture, fewer bureaucratic hurdles need to be overcome. Additionally, many of the parcels in this area are considered heritage land so there is little threat of development. Much of the infrastructure is already in existence and designed for farming operations.
The area in which the parcel is located offers an agricultural community, something that rural farmers have long recognized as crucial for the success of farming ventures (Henderson \& Van En, 2007). Due to increasing development around the park, greater potential for attracting CSA members exists, as well as simplified distribution structures. A significant opportunity for this scenario is that the owner of the land, Toronto and Region Conservation Authority (TRCA), has a sustainable agriculture policy that aims to promote more sustainable agriculture and local food distribution on conservation land. TRCA has been working with FarmStart, an organization that trains and supports new farmers, to provide affordable land at the McVean farm, 94 acres (38 hectares) of land within Claireville Conservation Area in Brampton, Ontario, just northwest of Toronto. In this farm scenario, the TRCA could implement a similar initiative as at the McVean farm and lease out a portion of the parcel to a CSA farmer.

\section{(c) Commercial land scenario}

A number of parcels we identified have a private company located on or near the parcel.

This particular parcel is 17.5 acres (7.1 hectares) in size and sits on the south side of Steeles Avenue between Victoria Park Avenue and Pharmacy Avenue (thus on the border of Toronto and Markham). It is on the property of a financial institution that also has an office building on-site and, as the owner of the parcel, maintains the site regularly and keeps it in mowed grass. It is zoned as "Employment," which does not permit agriculture.

Many opportunities exist with this type of parcel. From a physical perspective, the company is maintaining the land, and so implementing agriculture should be relatively easy. A water source is likely to be nearby, and while there are no structures on-site, the office building could offer a potential storage space for tools and other equipment.

As companies are often looking for ways to engage their employees, having a CSA farm on-site is an innovative way for the financial institution to get employees more engaged in the workplace. There are growing examples of workplaces partici- 
pating in CSA programs for the purpose of promoting employee wellness. Community Involved in Supporting Agriculture (CISA) is a nonprofit organization based in Massachusetts that facilitates CSA membership with employees of seven different companies (Community Involved in Supporting Agriculture, 2008). Another example is Washington Wellness, an organization that works with Washington state agencies to implement CSA programs at their workplaces in recognition of the positive impact on health and wellness of employees (Washington Wellness, 2011). Opportunities also exist for businesses to work with insurance companies to encourage employee involvement in CSA. In Wisconsin, Madison Area Community Supported Agriculture Coalition (MACSAC) partnered with health management organizations to offer rebates to insurance policyholders who purchase shares in vegetable CSA farms (Jackson, Raster, \& Shattuck, 2011). They recognized that it costs insurance companies less money when policyholders make healthful lifestyle choices. The myriad effects of this program include increased fruit and vegetable consumption, substantial growth in the number of CSA farms, and greater public interest in supporting local food initiatives (Jackson, Raster, \& Shattuck, 2011).

From volunteering labor to being recipients of the produce to receiving education about farming and gardening, there are myriad opportunities for employees to benefit from this kind of venture. In addition, if employees are the major recipients of the shares, distribution is simplified and more environmentally friendly. It may also raise the profile of the company, and the high visibility of the venture (located at the corner of major streets) can be good publicity for both the farm and the company.

One of the challenges, as with other parcels, is that the zoning would need to be changed. Another issue is that companies often have development plans, and the parcel could just temporarily be fallow prior to expansion of the company. In this case, the financial institution has been planning to use the space for a research facility, but the land has been fallow for a number of years.

\section{(d) Fallow land}

Numerous parcels were identified that are likely privately owned, but there is no existing company or institution on the property. These parcels are interspersed throughout the city, often in industrial pockets.

This particular parcel is actually made up of three parcels adjacent to each other, making up almost 30 acres (12 hectares) in total, located in east Scarborough. While the parcels sit within an industrial area, directly to their east is a fairly new residential area. The parcels are mainly in scrub vegetation, with no structures on-site and hydro towers located next to the parcels. The parcels are owned by a company for which little information could be found but is likely a development firm. The parcels are zoned as "Industrial," which does not permit agriculture.

Establishing CSA farms on these types of parcels presents numerous challenges, but some opportunities do exist. Often located in areas considered "undesirable," having a CSA farm could raise the profile of these areas. With new development occurring around these parcels, there is also a potential market for farm products in close proximity.

From a physical perspective, one of the challenges with these parcels is converting the land to agriculture, which may require extensive work that includes the reduction of perennial weeds. There is also a greater chance that the land could be contaminated from previous industrial activities. Infrastructure tends to be limited on these types of parcels, so establishing necessities such as access to water may require considerable effort.

From an administrative perspective, it is often difficult to determine the owner and development plans for the parcels and therefore to assess the likelihood for implementing CSA farming. Knowing its projected evolution is critical, as it is highly unlikely that any private owners of land slated for development would allocate it to a small organic CSA farm.

\section{(e) Small parcel (i.e., close to the minimum acreage size criteria)}

These smaller parcels are often located in much more "urban" areas than those mentioned above, 
such as in city parks.

This particular parcel is about 6.6 acres $(2.7$ hectares), located in a park next to a subway station and residences and bordered on one side by the Humber River, in Etobicoke. There are a few small buildings on the northern tip of the parcel belonging to a private recreation organization whose main function is renting boats and facilities for private functions. The parcel is zoned as "Private Open Space," which allows agricultural activities, including market gardening, but not animal slaughter.

This site appears to have fewer barriers to agricultural development than others already described. One of the opportunities with this type of parcel is its proximity to potential members; therefore, distribution would likely be simplified. The set-up of infrastructure would be relatively easy given that water is available and there are structures on-site for equipment storage. Zoning for this parcel does not need to be changed. This type of small space would be an opportunity to pilot SPIN farming, a fairly new type of intensive vegetable crop production and business model that allows for profitability from small garden spaces.

A challenge would be that as part of the land owned by a recreation organization, the parcel likely sees a lot of pedestrian traffic during the summer months, and the activities of the club may not co-exist well with those of a CSA farm.

\section{Common Scenario Elements and General Considerations}

While the above scenarios described would vary greatly if CSA farms were established on the parcels, there are some common elements that would likely exist within any of these farms.

\section{Labor}

Small organic farming operations are often laborintensive; having dependable, affordable labor is crucial. While rural farms may have trouble attracting this kind of labor, recruiting in the city may be easier for at least semiskilled labor. Some sources could include:

- Agricultural internships. The Collaborative Regional Alliance for Farmer Training
(CRAFT) program has been quite successful at matching interns looking for sustainable farming experience with organic farms in rural areas, and this model could work well in the city. The Toronto Urban Growers, an organization of urban agriculture advocates, is examining internships through the various urban agriculture projects existing in Toronto. Examples exist on the fringes of the city with internships offered through small organic farms established in Woodbridge and Brampton.

- High school co-op programs. There are an increasing number of elementary and high schools implementing gardens on their property to increase awareness of food security and teach growing skills (Bain, 2009). Creating a co-op around agriculture could be a natural addition to these initiatives. Very recently, Bendale Business \& Technical Institute in Scarborough partnered with FoodShare to create Canada's first-ever school-based market garden. Using less than an acre (0.4 hectare) of space, students are involved in food production under the supervision of a farm manager, as well as the marketing of the produce and food preparation.

- General community. Many people are unable to commit to full-time farm work, but enjoy getting involved in different aspects of growing food and would be willing to volunteer their time on a farm. Free or cheap advertising to the general public could occur at community centers, public libraries, and retail stores.

- Members. Included in the agreement with members could be mandatory hours that have to be worked, whether it is in the field or administrative tasks. This allows for more harvesting to be done by actual members and makes distribution much easier. Involving members can also save costs in terms of needing refrigeration and storage space on-site.

\section{Agricultural production}

To be consistent with other city initiatives, organic methods of cultivation would be required on all farms in these scenarios, which means at a minimum that no synthetic fertilizers or pesticides 
be used. Organic agriculture allows for increased environmental stewardship, healthier produce, and is consistent with numerous policy directives of the city and the province's ban on cosmetic use of pesticides.

Building the soil and utilizing compost to fertilize the soil are important concepts of organic farming. Urban farms are different from rural farms in that they may not have the space or the livestock to create fertility on-site, and they also do not have other farms nearby from which they can source extra manure or straw. To minimize the use of external sources of fertility and maintain a closed loop system, there would be as much composting on site as possible. Vermicomposting is something that many urban farms practice and could be ideal for urban farms' small sites. If there is a network of urban farms, perhaps purchasing cooperatively is an option, where large amounts of compost could be purchased at a lower cost and from an appropriate source.

Soil testing would also be needed for all sites, and the responsibility for this can be negotiated between owner and farmer and included in the lease arrangement. The city of Toronto has recently developed a protocol for soil testing and remediation that would aid gardeners/farmers in developing ideal soil conditions for food production. Contaminated sites requiring extensive remediation would be excluded from consideration in the parcels for leasing.

\section{Membership and distribution}

Equitable distribution is a key issue that comes up in any urban farming scenario. How is membership determined? One potential scenario would be that with many of the land parcels, shares may first be offered to those affiliated with the property; for example, if it is on land owned by a company, shares would be offered first to company employees. Then, advertising within the immediate community would be a priority in terms of establishing membership. This would include making special efforts to do outreach in ethnically diverse neighborhoods. If the membership is not completely filled from within the neighborhood, then offering shares to the wider community would be the next step. Once the farm is established, farmers or organizers could create ways of including low-income members, using some of the strategies used by CSA farms in Canada and the U.S.

Research shows that CSA members tend to be fairly well educated, financially secure, female, middle-aged, and have children (Goland, 2002; Landis, Smith, Lairson, McKay, Nelson, \& O'Briant, 2008). They also are more likely to be Caucasian and share an interest in organic produce, sustainable food systems, protecting the environment, and supporting local farmers (Cone \& Myhre, 2000; DeLind, 1999; Lang 2005). These characteristics are important to note as many of the parcels identified are located in ethnically diverse neighborhoods with varying types of families and income levels. Perhaps CSA farmers will need to test out different strategies in order to connect to the populations in their area. There are certainly growing examples of CSAs diversifying their membership by including low-income members and catering to specific ethnic groups (Henderson \& Van En, 2007).

In general, urban farms do not have the same complex distribution arrangements as rural farms. With all of the potential farms in this research located within 3.1 miles $(5 \mathrm{~km})$ of neighborhoods (see figure 1 and 2), it can be expected that residents would come to the farm to pick up their weekly baskets. Alternative modes of transport for picking up produce could be strongly encouraged to avoid an increase in vehicle traffic and subsequent greenhouse gas emissions. If necessary, the membership agreement between CSA farmer and member could contain stipulations around transportation to the farm and incentive programs could be employed to reduce individual trips to the farm. The exception to this would be for a farm in Rouge Park, for example, whose membership may be more far-flung, requiring a delivery van to do home deliveries or to drop off at a pickup location.

\section{Partnerships}

By nature of their urban settings, city farms often not only operate as food growers but also serve other cultural and social functions. As the literature reveals, urban farms frequently partner with nonprofit organizations, community agencies, and 
institutions to offer education, food donations, skills training, tours, and other programs. For example, Black Creek Urban Farm in northwest Toronto has partnered with the Composting Council of Canada, Afri-Can Food Basket, Toronto Public Health, and Starbucks Coffee Company (Toronto and Region Conservation Authority [TRCA], 2008).

\section{Livelihood opportunities}

What has become apparent in creating these scenarios and from studying the literature is that there is significant opportunity to expand on and enhance sustainable occupations in the food sector in urban areas. In addition to the role of urban CSA farmer, there will be opportunities for others involved in the production, processing, marketing, and distribution of food and necessary inputs (see MacRae et al., 2012, for a description of some of the related support services for urban agriculture that include income-generating potential). In addition, with a governmental body established to manage an urban agriculture program, opportunities will become available for people to administer various aspects of the program. As these urban CSA farms will likely partner with nonprofit organizations and other community agencies, opportunities in educational or recreational programming will become available, such as children's gardening and horticultural therapy.

\section{Conclusions and Recommendations}

\section{Recommendations}

MacRae et al. (2012) provide an extensive set of policy recommendations to support urban agriculture in general. They recommend that the city of Toronto form a governing body to administer an urban agriculture management plan. This would include producing a comprehensive land analysis; examining zoning issues; formulating a request for proposals (RFP) process; creating a template for leasing arrangements; examining insurance, taxing, fair rental rates, water, and other infrastructural supports; advertising to the public; and monitoring the projects. Here, we elaborate on some additional elements that are more specific to CSA models. While the vision of CSA farms located throughout the city of Toronto is currently an idea on paper, the following recommendations could move this vision closer to reality.

1. Initiate a small number of CSA farms on TRCA-owned land in Rouge Park. Due to the zoning that allows agricultural activities, the existence of infrastructure, and TRCA's vision of supporting near urban agriculture, this would be a place to begin.

2. The city or other agencies could initiate a campaign aimed at private landowners around lending their land for urban agriculture projects and provide some support by helping to match urban farmers to landowners and giving guidance on lease arrangements.

3. Pilot a small number of projects, perhaps led by nonprofit organizations, in different locations and assess opportunities and challenges from these projects.

4. Conduct research into SPIN farming (Satzewich \& Christensen, 2007). There are examples of this farming method producing a significant amount of food on very small parcels, while providing the farmer with an adequate income. Some of these examples use a CSA model; this method should be explored further and tested on small plots of land.

5. Continue to explore partnerships between urban agriculture projects and rural farms. Many urban farms written up in the literature or in popular media have such arrangements, with much of the produce grown outside the city but with the urban location providing supplemental production and a base for urban CSA members. This could strengthen urbanrural linkages and highlight the need to preserve farmland outside the city.

6. With any CSA, emphasis should be placed on engaging the local community. If a parcel is located within a low-income area, organizers need especially to look into strategies for including low-income residents of the community. There are many examples of this being done, some specific to the United States.

\section{Concluding Remarks}

What is the potential for CSAs in the city of 
Toronto? While it is impossible to have a completely accurate estimate of which parcels of land would do well as CSA farms - since obtaining complete profiles on all the parcels is challenging - the data do provide some useful information. The parcels in the northeast part of Scarborough, within Rouge Park, seem to possess many of the elements required of a successful CSA within the city. They are zoned agricultural, have much of the needed infrastructure in place, and are large enough to accommodate a range of farming activities. Increasingly, as development around Rouge Park continues, these farms could sell their produce to community members only a short distance away.

Broad challenges do exist with this vision of urban CSAs in the city of Toronto. Finding experienced CSA farmers who are able to grow organically and can adjust to urban constraints may be a challenge. While there are many young urbanites who are interested in engaging in ecological agriculture, becoming a skilled farmer requires years of practice and mentoring. This is another reason to incorporate new farmer training into urban agriculture initiatives. Just as rural farmers often rely on other farmers for exchange of goods, information, and services, urban farming requires similar networks.

Equitable distribution will always be an issue in an urban setting where the amount of food produced is quite small compared with the population's needs. In Toronto, farms will likely not be located in the particular areas where demand for local and organic food is high. For example, a farm in east Scarborough may have more interested downtown Toronto residents than those living right next to the parcel. Urban CSAs have the opportunity to engage people who may not be considered the typical sustainable food consumer. Additionally, CSAs can take advantage of the relationship between farmer and member to address the needs and wants of low-income community residents or a specific ethnic group.

In any urban area, debates will exist about the best use of land. For example, while many of the farms in Rouge Park are designated "Agricultural Heritage Land" and therefore will remain reserved for agriculture, tensions still exist between supporting farming and supporting conservation on the lands in this park.

According to the data collected, a very small percentage of Toronto's population would be able to supply a significant portion of their diet through urban CSAs, and there are considerable challenges to widely implementing CSAs. While one might wonder if it is worth the individual and public effort and investment, urban CSA farms could provide many potential benefits. The beauty of urban CSAs is not so much the amount of food they can produce, but the platform they provide to accomplish other things. The possibility to contribute significantly in many meaningful ways to the health of communities suggests the effort is worthwhile.

\section{Acknowledgements}

Many thanks to Eric Gallant and Stephanie

Schaffner for assistance with research and map preparation.

\section{References}

Bain, J. (2009, September 29). Reading, writing, growing. Toronto Star. Retrieved from http://www.foodshare.net/media archive96.htm

Biberstein, R., \& Daalderop, M. (2008). The Good Food Box: A Manual, $2^{\text {nd }}$ Edition. Toronto, Ontario: FoodShare.

Coleman, E. (1995). The new organic grower: A master's manual of tools and techniques for the home and market gardener. White River Junction, Vermont: Chelsea Green Publishing.

Community Involved in Supporting Agriculture. (2008). Community supported agriculture for the workplace. Massachusetts: Author.

Cone, C. A., \& Myhre, A. (2000). Community supported agriculture: A sustainable alternative to industrial agriculture? Human Organization, 59(2), 187-198.

DeLind, L. B. (1999). Close encounters with a CSA: The reflections of a bruised and somewhat wiser anthropologist. Agriculture and Human Values, 16(1), 3-9. http://dx.doi.org/10.1023/A:1007575521309

De Zeeuw, H. (2004). The development of urban agriculture: Some lessons learnt. Keynote paper for the International Conference Urban Agriculture, AgriTourism and City Region Development. Beijing: RUAF. 
Équiterre. (2002). Proceedings from Conference on Community Supported Agriculture: To Harvest, To Eat, To Share. Montreal, Quebec: National Library of Quebec.

Équiterre. (2011). Community supported agriculture in figures. Accessed on October 25, 2011, from http://www.equiterre.org/en/projet/communitysupported-agriculture/community-supportedagriculture-in-figures

FoodShare. (2008). How to start a community garden. Toronto, Ontario: FoodShare.

Goland, C. (2002). Community supported agriculture, food consumption patterns, and member commitment. Culture and Agriculture, 24(1), 14-25. http://dx.doi.org/10.1525/cag.2002.24.1.14

Henderson, E., \& Van En, R. (2007). Sharing the harvest: A guide to community-supported agriculture. White River Junction, Vermont: Chelsea Green Publishing.

Horst, M. (2008). Growing green: An inventory of public lands suitable for community gardening in Seattle, Washington. Seattle, Washington: University of Washington.

Jackson, G., Raster, A., \& Shattuck, W. (2011). An analysis of the impacts of health insurance rebate initiatives on community supported agriculture in southern Wisconsin. Journal of Agriculture, Food Systems and Community Development, 2(1), 287-296 . http://dx.doi.org/10.5304/jafscd.2011.021.002

Kaethler, T. M. (2006). Growing space: The potential for urban agriculture in the city of $V$ ancouver. Vancouver, British Columbia: City of Vancouver.

Landis, B., Smith, T., Lairson, M., McKay, K., Nelson, H., \& O'Briant, J. (2008). Fruit and vegetable intakes and demographic characteristics of community supported agriculture program participants in North Carolina. Journal of the American Dietetic Association, 108,9, Supplement, A71.

http://dx.doi.org/10.1016/j.jada.2008.06.184

Lang, K. B. (2005). Expanding our understanding of community supported agriculture (CSA): An examination of member satisfaction. Journal of Sustainable Agriculture, 26(2), 61-79. http://dx.doi.org/10.1300/J064v26n02 06

Lass, D., Stevenson, G. W., Hendrickson, J., \& Ruhf, K. (2003). CS $A$ across the nation: Findings from the 1999

CS A Survey. Madison, Wisconsin: Center for Integrated Agricultural Systems.

MacRae, R., Gallant, E., Patel, S., Michalak, M., Bunch, M., \& Schaffner, S. (2010). Could Toronto provide
$10 \%$ of its fresh vegetable requirements from within its own boundaries? Matching consumption requirements with growing spaces. Journal of Agriculture, Food Systems and Community Development, (1) 2, 105-127. http://dx.doi.org/10.5304/jafscd.2010.012.008

MacRae, R. J., Nasr, J., Kuhns, J., Baker, L., Christianson, R., Danyluk, M., ...Wekerle, G. (2012). Could Toronto provide 10\% of its fresh vegetable requirements from within its own boundary? Part II: Policy supports and program design. Journal of Agriculture, Food Systems and Community Development, 2(2), 147-169. http://dx.doi.org/10.5304/jafscd.2012.022.002

McClintock, N., \& Cooper, J. (2009). Cultivating the commons: An assessment of the potential for urban agriculture on Oakland's public land. Oakland, California: Food First.

McFadden, S. (2012). Unraveling the CS A number conundrum. Retrieved from http://thecalloftheland. wordpress.com/2012/01/09/unraveling-the-csanumber-conundrum/

Miles, A., \& Brown, M. (Eds.). (2005). Teaching direct marketing and small farm viability: Resources for instructors. Center for Agroecology and Sustainable Food Systems, University of California, Santa Cruz.

Mougeot, L. J. A. (2006). Growing better cities: Urban agriculture for sustainable development. Ottawa, Ontario: International Development Research Centre.

Norberg-Hodge, H., Merrifield, T., \& Gorelick, S. (2002). Bringing the food economy home: Local alternatives to global agribusiness. London: Zed Books.

Ontario CSA Directory. (2012). Directory of community supported agriculture in Ontario. Retrieved on January 16, 2012, from http://csafarms.ca/CSA\%20farmers.htm

Organic Council of Ontario [OCO]. (2009). Organic Council of Ontario Community Supported Agriculture Survey. Fergus, Ontario: Mallet Creek Strategies.

Portland State University. (2005). The diggable city: Making urban agriculture a planning priority. Portland, Oregon: City of Portland.

Pretty, J., Brett, C., Gee, D., Hine, R. E., Mason, C. F., Morison, J. I. L.,... Van der Bijl, G., (2000). An assessment of the total external costs of UK agriculture. Agricultural Systems, 65, 113-136. http://dx.doi.org/10.1016/S0308-521X(00) $\underline{00031-7}$ 
Russell, W. S., \& Zepeda, L. (2008). The adaptive consumer: Shifting attitudes, behaviour change, and CSA membership renewal. Renewable Agriculture and Food Systems, 23, 136-148. http://dx.doi.org/10.1017/S1742170507001962

Satzewich, W., \& Christensen, R. (2007). SPIN Farming: How to grow commercially under an acre. Saskatoon, Saskatchewan: Wally's Urban Market Garden.

Smit, J., Ratta, A., \& Nasr, J. (1996). Urban agriculture: Food, jobs and sustainable cities. Retrieved from http://www.jacsmit.com/book.html

Tegtmeier, E. M., \& Duffy, M. D. (2004). External costs of agricultural production in the United States. International Journal of Agricultural Sustainability, 2(1), 1-20.

http://dx.doi.org/10.1080/14735903.2004.9684563

Tegtmeier, E. \& Duffy, M. (2005). Community supported agriculture (CSA) in the Midwest United States: A regional characterization. Ames, Iowa: Leopold Centre for
Sustainable Agriculture. Retrieved from http://www.leopold.iastate.edu/pubs-and-papers/ 2005-01-community-supported-agriculture Toronto and Region Conservation Authority [TRCA]. (2008). Toronto and Region Conservation Authority Annual Report 2008. Retrieved from http://www.trca.on.ca/about/

Washington Wellness. (2011). Guide to CS A delivery at state worksites. Seattle, Washington: Author.

Willick, F. (2008). Community shared agriculture primer: The ins and outs of running a CSA farm in Ontario. Guelph, Ontario: Ecological Farmers Association of Ontario, Canadian Organic Growers, Ignatius Farm CSA. Available from http://www.gardenparty.ca/publications Worden, E. C. (2004). Grower perspectives in community supported agriculture. HortTechnology, 14(3), 322-325. 